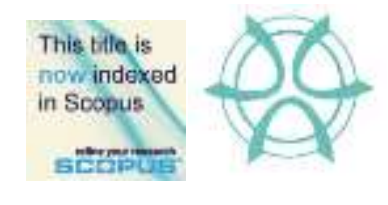

PLANNING MALAYSIA:

Journal of the Malaysian Institute of Planners

Volume XIII (2015), Page 85 - 100

\title{
THE ROLES OF URBAN HERITAGE IN DETERMINING THE IMAGE OF THE ROYAL TOWN OF SRI MENANTI, NEGERI SEMBILAN
}

\author{
Nor Zalina Harun ${ }^{1}$, Dg. Norhidayah Fairuz ${ }^{2} \&$ Nor Adilla Nordin ${ }^{3}$ \\ ${ }^{1,2,3}$ Kulliyyah of Architecture and Environmental Design \\ INTERNATIONAL ISLAMIC UNIVERSITY OF MALAYSIA
}

\begin{abstract}
Malaysia has many towns of historic and cultural significance that are worthy of preservation for sustainable development. For instance, a royal town, which is a town where the old palaces and the royal administrative district are located. This paper aims to discover the significance of the urban heritage of a royal town so as to ensure its preservation. Special attention is paid to the identification of townscape elements in forming the image of the town and the roles of the townscape elements as built heritage of the royal town. A case study was carried out in Sri Menanti, Negeri Sembilan, which is one of the royal towns in Malaysia. The study methodology involves a historical map overlay, non-participant observation and semi-structured interviews. The findings reveal that Sri Menanti has played a significant role in the history and development of Negeri Sembilan. Additionally, the contribution of 'Adat Perpatih' to the nation's history as one of the unique administrative components helps to signify the importance of the town's local culture and urban heritage. The town also represents a number of townscape elements that are intertwined as urban heritage, with rich cultural and architectural significance. The paper concludes that diversity in the character of the town is unique and worthy of preservation.
\end{abstract}

Keyword: Urban heritage, townscape elements, preservation, royal town Sri Menanti 
Nor Zalina Harun, Dg. Norhidayah Fairuz \& Nor Adilla Nordin

The Roles of Urban Heritage in Determining the Image of the Royal Town of Sri Menanti, Negeri Sembilan

\section{INTRODUCTION}

In Malaysia, historical and cultural significance plays an important role in shaping the identity, structure and meaning of towns. Royal towns, in particular, have high historical and cultural values that are worthy of preservation. Nevertheless, extensive urbanisation and rapid development have eroded the significance of these towns.

The primary aim of this paper is to discover the significance of urban heritage of a royal town to ensure its preservation. This preservation of the urban heritage should not only cover certain monuments and sites, but should also extend to the level of preservation of all properties of historic and cultural significance involving the tangible and intangible elements. Therefore, in this study, several objectives are set, the first of which is to identify the elements of the urban townscape that form the image of the town using historic map overlay, non-participant observation and semi-structured interviews. The resulting findings on elements of the urban townscape are categorized according to their physical and cultural significance in the royal town.

The second objective is to understand the roles of the townscape elements as urban heritage of the royal town. This is because the townscape elements identified in the royal town may have high potential to become part of the urban heritage. As the research focuses only on a single case study in Sri Menanti Royal Town, an overall picture of the characteristics of royal towns in Malaysia cannot be generalized. However, it is hoped that this study might help in signifying the importance of royal towns in the nation's history.

\section{THE CHARACTER OF A ROYAL TOWN}

A royal town is defined as a town that has high value in terms of historical and cultural significance, and shows a strong relationship between the growth of the community and the development of the urban landscape, especially in terms of the built elements (Royal City Comprehensive Plan, 2009). In addition, the identity of a royal town is based on the presence of old palaces and royal administrative districts, which are the key aspects that form the identity of the town.

Malaysia has a number of royal towns, such as Kuala Kangsar in Perak, Arau in Perlis, Klang in Selangor, Seri Menanti in Negeri Sembilan, Pekan in Pahang, Anak Bukit in Kedah and Muar in Johor (Utusan Online, 2009). Each of these royal towns has its own historical and cultural characteristics that help to distinguish between these towns through the alignment of minor or major building fabrics, forming the area into valuable urban masterpieces (Dalmas, Geronimi, Mengin, Noel \& Patin, 2012). It is important to preserve these royal towns, as they are testament to the greatness of the monarchy system of the Malay Royal Institution (Muslim, Wan Hassan \& Umar, 2013). However, in order to 
PLANNING MALAYSIA

Journal of the Malaysia Institute of Planners (2015)

preserve a royal town, it is important to firstly identify the significance of its urban heritage through the identification of its key townscape elements.

\section{Types of Urban Townscape Element}

When defining the visual image of a royal town, an in-depth understanding of its physical form is essential. Lynch (1990) has classified the elements of the physical form into five main categories, which are paths, edges, district, nodes and landmarks. Path can be understood as the most significant elements within the town's development, as they help in supporting human movement along the streets, walkways, transit lines, canals and railroads. They may be classified into several categories, such as primary, secondary and tertiary paths, or major and minor paths. Meanwhile, the line breaks or barriers that help in defining the region of the town are known as edges. The district is defined according to the elements that become guide points outside the town. Another type of urban townscape element, known as nodes, can be defined as the focal points or loci in the town or strategic places where people congregate. Finally, landmarks are defined as points of reference, either physical objects such as buildings, signs, stores or mountains. An understanding of the urban townscape elements may help the researcher to understand the physical pattern of the urban fabric in detail.

\section{Urban Heritage}

The physical pattern of the urban heritage in a royal town has been shaped over the centuries, portraying the reformation of the heritage landscape through the interaction of nature and culture. This interaction can be seen in terms of the elements of the urban heritage that symbolize the identity, structure and meaning of the royal town. This is because the urban heritage is based on a concept that requires a combination of historical, sociological and economic approaches by the society towards the local people of the urban area. However, industrialisation has caused the growth of urbanisation within the area of the royal town, affecting valuable elements of its urban heritage. Therefore, each individual, whether a local citizen or a government official, should have a deep understanding of the specific definition of the evolution of the historic structure and material elements of the urban heritage in a royal town in order to preserve its values.

Even though the historical structure and material elements have become the main physical elements embodying the spirit of the place, the value of urban heritage is on the relationship between humans and nature in order to create a strong sense of belonging within the town. The concept of the sense of belonging might be achieved through the preservation of the vividness of cultural traditions over the development of the industrial sectors within the urban area.

Urban heritage may be simplified by classifying its components into three main categories, which are monumental heritage of exceptional cultural value, non-exceptional heritage elements that are present in a coherent way and in 
Nor Zalina Harun, Dg. Norhidayah Fairuz \& Nor Adilla Nordin

The Roles of Urban Heritage in Determining the Image of the Royal Town of Sri Menanti, Negeri Sembilan

relative abundance, and new urban elements to be considered, such as the urban built form, the open space, streets, public open spaces, and urban infrastructures such as material networks and equipment.

In Malaysia, conservation of heritage items, including national heritage, natural heritage, tangible and intangible cultural heritage and related matters, are govern by the National Heritage Act 2005. The Act defines conservation of heritage items to include preservation, restoration, reconstruction, rehabilitation, adaptation or any combination of the said conservation methods. The aim of preservation, as stipulated in the Act, is to stop any deterioration, decay or state of dilapidation and provide structural safety and well-being.

\section{METHODOLOGY}

In order to identify the significant role of urban heritage of a royal town, historical map overlay, non-participant observation and semi-structured interviews were employed in data collection. The data were then analysed to determine results from all forms of data collection were later analysed in order to achieve a comprehensive understanding of the findings.

\section{Study area}

Sri Menanti, in Negeri Sembilan, was selected as the case study area because it has the characteristics of both historical and cultural significance that might help in distinguishing this royal town from other types of Malay Royal Institutional District. The town is selected due to the presence of its old palace, which acted as the former administrative centre of the state (Md Jani \& Mohd Hussain, 2014). Sri Menanti is located $6 \mathrm{~km}$ off the Seremban-Kuala Pilah road and surrounded by green stretches of paddy fields and row of hills, forming the pattern of the physical landscape in Sri Menanti. The Minangkabau architectural influence is strongly visible in this area. The main economy of the area is agriculture.

\section{Historical Map Overlay}

This method was used in order to get a better understanding of the role of townscape in providing the image, identity and meaning of the town. According to Shamsuddin (2013), the pattern form of the development of the townscape is due to the accumulation of buildings from different periods, from the initial development of the town until the present time. Therefore, the layout and structure of Sri Menanti were studied based on the physical components, comprising the characteristics of the natural landscape, urban structure and architectural features. Also studied were fundamental geographical reasons for settlement formation, dominant buildings of historical significance and the movement pattern of ancient origins based on changes to the seat of power, economic and functional patterns within the town. Then, a series of historical 
PLANNING MALAYSIA

Journal of the Malaysia Institute of Planners (2015)

maps was analysed in order to determine all the factors that contributed to the formation of the townscape elements in the study area.

\section{Non-participant Observation}

In general, non-participant observation is defined as a technique of data collection that might help in gaining a better understanding of the role of the townscape elements applied by the local people in Sri Menanti. The observation aims firstly to identify the types of element that exist in the town in order to relate to its function in the daily routine activities conducted by the local people. The data collection specifically contributes to ideas on the physical and social background that form the identity of the whole town. Sketches and mapping were used to record the data from the observation.

\section{Semi-Structured Interviews}

In order to develop a deep understanding of the historical and cultural background of the Royal Town in Sri Menanti, semi-structured interview method was also used for data collection. The interview focussed on understanding the relationship between social characteristics and environmental, social and economic factors. Respondents were Encik Azhar, Head of Jawatankuasa Kemajuan dan Keselamatan Kampung (Village Development and Safety Committee), Dato' Bangsa Balang Mohamad Dahalan Alias, the Head of the Luak in Sri Menanti, Encik Nordin Jonid, Officer at Muzium Diraja Istana Sri Menanti (Sri Menanti Royal Palace Museum), Encik Afian Abd. Kadir, Officer of Muzium Kebudayaan Negeri Sembilan (Negeri Sembilan Cultural Museum), and a few local people with knowledge on the history of the study area. The information gathered from the interviews were later screened, transcribed and analysed.

\section{FINDINGS AND DISCUSSIONS}

The results of the analyses indicate that the royal town image of Sri Menanti was defined by several elements. These can be categorised into physical and social components. The physical component comprises the characteristics of the natural landscape, the urban structure and architectural features. Meanwhile, the social component comprises the social background and cultural significance of human activities in the study area.

\section{Landscape Characteristics of Sri Menanti}

Geographically, Sri Menanti is a town specifically located within the area of the Kuala Pilah District. Developed within the valley and surrounded by hilly terrain that acts as a natural predominant line breaker that separate the Sri Menanti from other towns (see Figure 2). The physical pattern of the natural landscape has influenced the structure and function of the urban form of the town. This can be 
Nor Zalina Harun, Dg. Norhidayah Fairuz \& Nor Adilla Nordin

The Roles of Urban Heritage in Determining the Image of the Royal Town of Sri Menanti, Negeri Sembilan

seen through the relationship between human behaviour and the environmental setting (Shamsuddin, 2011).

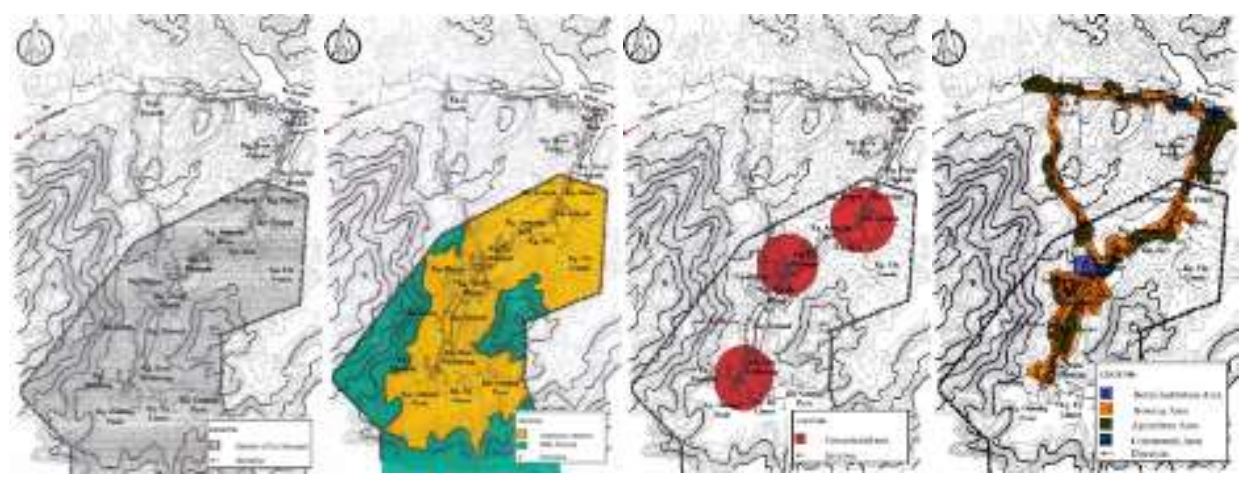

Figure 1: The historical map of Sri Menanti. a) District map; b) Settlement map; c)

Concentrated settlement area map; d) Land use map. Reproduced from https://www.google.com.my/maps

According to Abd. Kadir (personal communication, February 28, 2015), before the arrival of the immigrant people of the Minangkabau from the Sumatera, Sri Menanti was a hilly virgin forest wherein lied the settlements of the Malay-proto group known as the Sakai, Semang and Jakun (see Figure 1a). They had their own unique identity and culture in which they lived as a group that occupied the lowland area, depending on the forest resources (Mohd Sam \& Seow, 2013). The Malay-proto was a group ruled by a headman, known as 'Tok Batin'. He was the person who controlled the use of the land before the arrival of the immigrant people. However, the function of the hilly virgin forest gradually changed once the Minangkabau people started to settle in Sri Menanti. As shown in Figure 1b on the concentrated settlement area map, it is identified that the settlers started to take advantage of the physical character of the hilly and valley area of Sri Menanti by turning the lower hilly area into rice fields that acted as their main food crop area, although the valley area remained as the settlement area for the community as it was common practice for settlers to build their houses next to a stream running into the main river area (Gullick, 2003). This study indicates that the Minangkabau people understood the physical pattern of the hilly and valley area as an area that might drain water, sediments and dissolved materials to a common receiving body, or in other words, the functional characteristics of the land as the watershed area (O'Keefe et.al, 2015).

Due to the rising number of villages forming the Sri Menanti, the town became a liveable place that supported the community with rice cultivation became the main source of economy, which consequently led to the town becoming an administrative centre. Today, through observation, the valley area still remains as the main settlement area, while some of the lower hilly area 
remains as cultivation area, although cultivation is now predominantly through oil palm plantations rather than rice cultivation (see Figure 1d). In referring to the history of Sri Menanti, the oil palm plantation was introduced during the British colonialisation era in the late 19th century, during which time the British were focusing on the growth of commercial crops such as oil palm and rubber plantation. Therefore, it is demonstrated that the historical development of the Royal Town in Sri Menanti may have high significance for the physical characteristics of the urban pattern in the town (Shamsuddin, 2011).

\section{Urban Structure in Sri Menanti}

When looking at the natural features as the main structural characteristics of the town of Sri Menanti, the urban structure, in the form of the built elements, is the most dominant aspect of the town's identity. The town is basically a district with a single centre that allocates the commercial area, oriented by the administrative and residential area, which consists of a row of wooden shops and houses, a post office and police station and a health clinic (see Figure 2a). The profile of the town is best viewed from the hilly area, as the whole town can be easily recognised from afar due to the hilly terrain that appears as a backdrop and gives a distinctive view of the concentrated housing areas (see Figure $2 b$ and $2 b$ ).
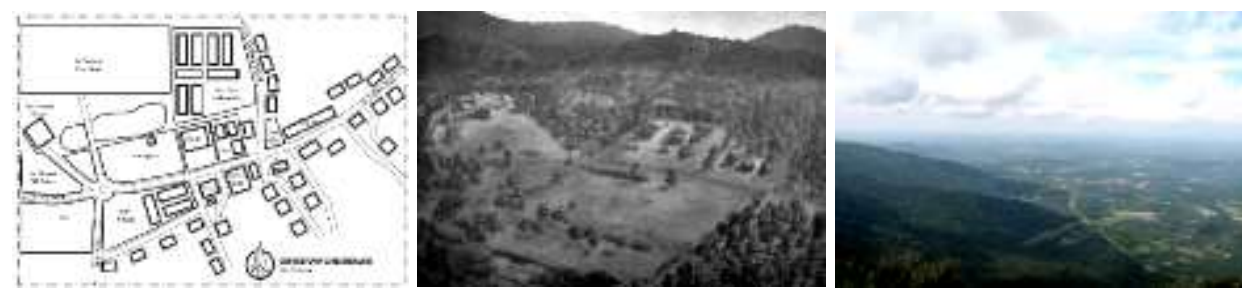

Figure 2: a) The map of the town centre; b) The illustration of the old view of Sri Menanti town; c) the current view of Sri Menanti.

The urban structure of Sri Menanti is upheld by the structure of its paths. The major paths in Sri Menanti are in the form of vehicular roads that spread perpendicular from the first road along the roads of Seremban-Kuala Pilah (see Figure 3a). The roads of Sri Menanti are characterised by the alignment of the traditional buildings along the side-roads, with modern buildings along the sideroad to Kampong Tanjung Ipoh. However, one element that shows the continuity of the roads is the alignment of the coconut and palm trees along the roadsides in front of the housing landscape compound. According to Gullick (2003), coconut is one of the alternative food crops in Sri Menanti. Therefore, it is not surprising that the roads are lined with coconut and palm trees. From the perspective of planting arrangements, the alignment of the coconut and palm trees helps in forming a physical barrier between the roads and the housing areas while creating a sense of direction (Walker, 1991). 

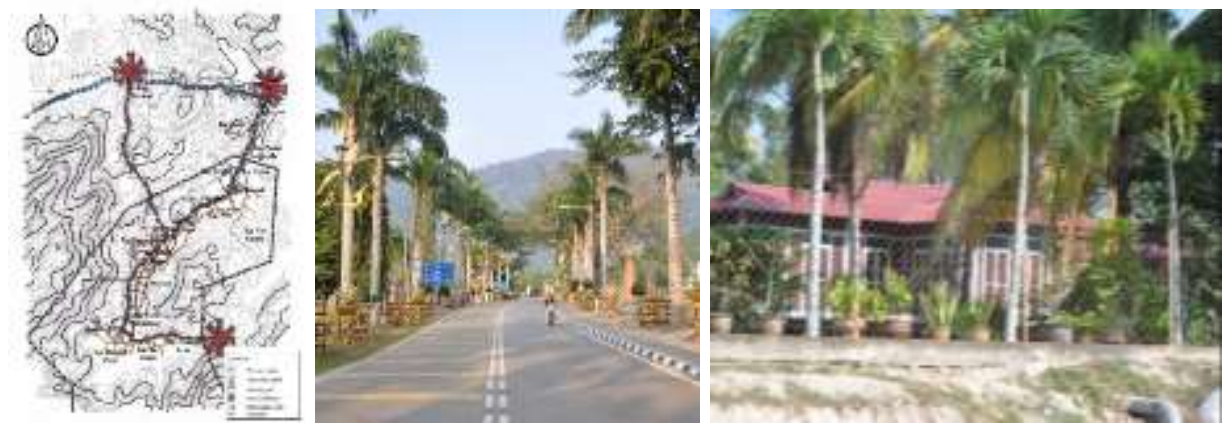

Figure 3: a) The circulation map; b) alignment of palm tree along the road that shows a sense of direction; c) palm trees planted in front of the housing compound that act as natural physical barriers

In addition, through observation, it is recorded that the design of the facilities is somewhat influenced and enhanced by the character of the royal town in Sri Menanti. Some of the facilities that give a sense of welcoming are the entrance archway, which uses the colours black and yellow, symbolizing the royal institution of Minangkabau in Sri Menanti, and the legibility of the signage at Sri Menanti, which is used to help identify the direction of the pathway (see Figure 4). The signage is designed to reflect the culture of the Minangkabau people.

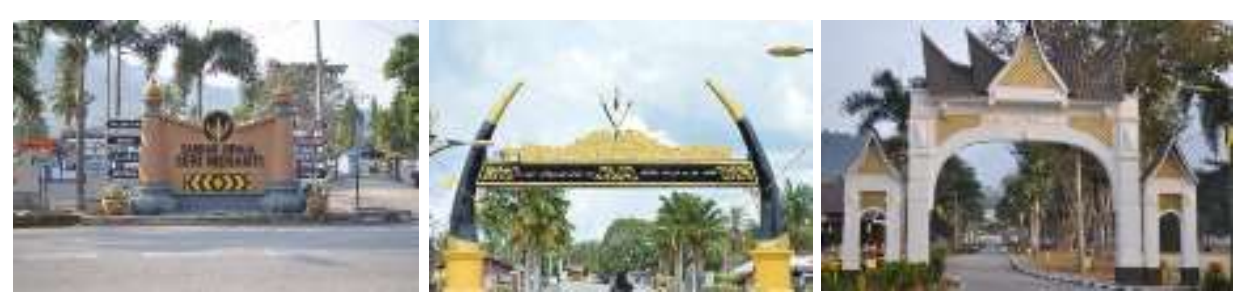

Figure 4: The signage in Sri Menanti, which shows the architectural characteristics of the Minangkabau

Therefore, through observation, it is clear that the characteristics of the urban structure in the Royal Town of Sri Menanti are upheld by the road system, which reflects the identity and values of the Royal Institution. It is also important to preserve and highlight the road system within the town, as this might help in supporting the movement of people through creating a certain level of familiarity with the town. 


\section{Architectural Features in Sri Menanti}

Another aspect of the built elements that show some significance in characterising the royal town in Sri Menanti is its architectural features. Through the observation conducted in Sri Menanti, it was identified that the major characteristics of the traditional houses and other buildings are influenced primarily by the Minangkabau architectural style (see Figure 5), with minor influence from the British architectural style.
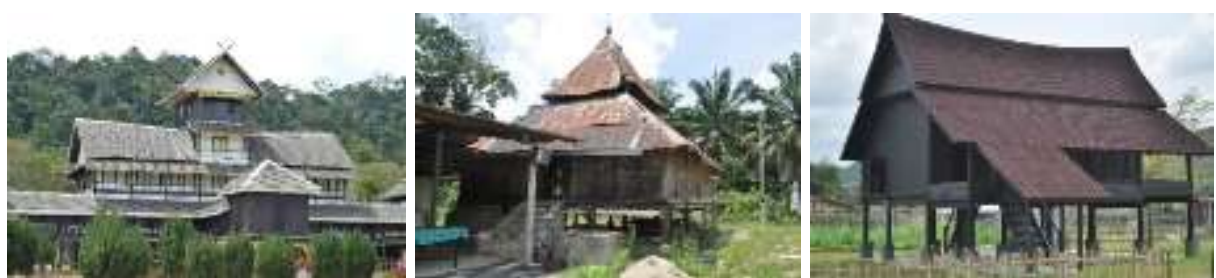

Figure 5: The traditional buildings and house that follow the Minangkabau architectural style; the Old Palace of Sri Menanti (left), old mosque located next to Masjid Kariah

Parit Istana (centre), half of the traditional house named as 'Rumah Ibu' located at Ladang Warisan (right).

The traditional buildings and houses were built mainly from wood using traditional construction skills that require no iron nails. Natural elements were adapted into the design of wood-carving in traditional buildings and houses in Sri Menanti, which help in characterising the cultural significance of the Minangkabau people. Some of the motifs used are believed by the villagers to have their own spiritual influences, such as the 'Sayap Layang-Layang', 'Naga Bekaluk', 'Itik Pulang Petang' and 'Buku Bembam' motifs (see Figure 6. Furthermore, some of the motifs also reflect the cultural belief of Islam. For example, the use of calligraphy as an aspect of the wood carving in the house.
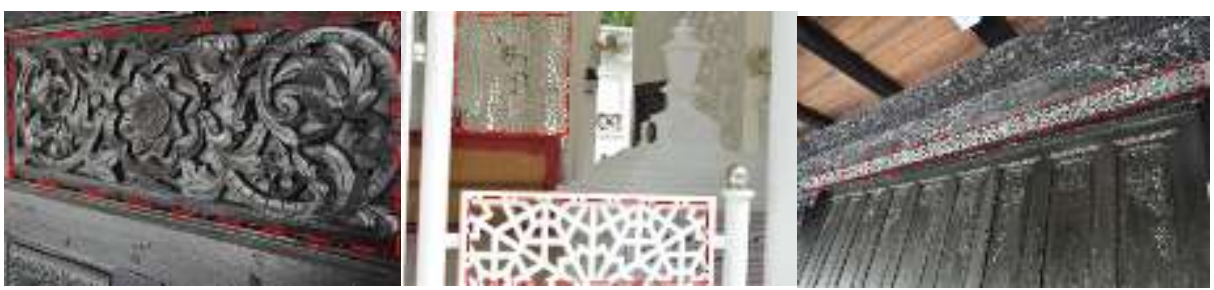

Figure 6: The 'Awan Larat' wood carving motif, symbolizing harmony among the

Minangkabau people (left); geometrical pattern symbolizing the Islamic culture (centre); calligraphy applied on the wall of a house showing the Islamic culture (right)

The most popular building in this town is the Old Palace of Sri Menanti, which is located next to Kampung Buyau. The Old Palace, reflects the Minangkabau architectural style, has become the main landmark within the town. 
Nor Zalina Harun, Dg. Norhidayah Fairuz \& Nor Adilla Nordin

The Roles of Urban Heritage in Determining the Image of the Royal Town of Sri Menanti, Negeri Sembilan

The four-level building dominates the skyline of the town, in which the level of the traditional buildings and houses in Sri Menanti should not be more than the height of the Old Palace (see Figure 7). According to the Officer of Muzium Istana Sri Menanti, the palace was built by two famous wood carvers, Tukang Kahar and Tukang Taib, using only materials from the local woods, and has become the iconic building of the monarchical system of the Malay Royal institution in Sri Menanti.

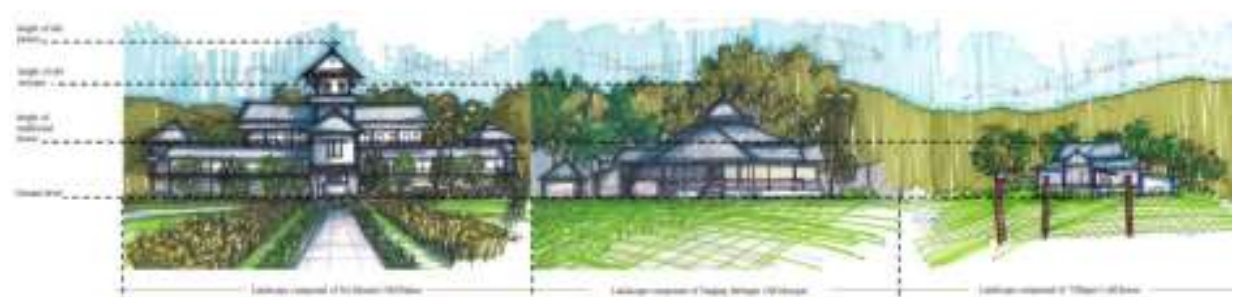

Figure 7: The hierarchy of the urban buildings in Sri Menanti Royal Town

Before the Old Palace of Sri Menanti was built, three other palaces had been built for the rulers of Sri Menanti (refer Figure 8). The palaces were called Barong-Barong (Istana Rambal), Istana Baruh and Istana Pulih, and were built under the Raja Melewar monarchy (1773) until Yamtuan Antah (1872). The Old Palace of Sri Menanti was built during the Yam Tuan Muhammad era. The construction of the palaces was similar in terms of position, with the hilly view in the background. However, today the only palace remaining is the Old Palace of Sri Menanti, which has been turned into a Royal Museum (Raja Shahminan et al., 2009).

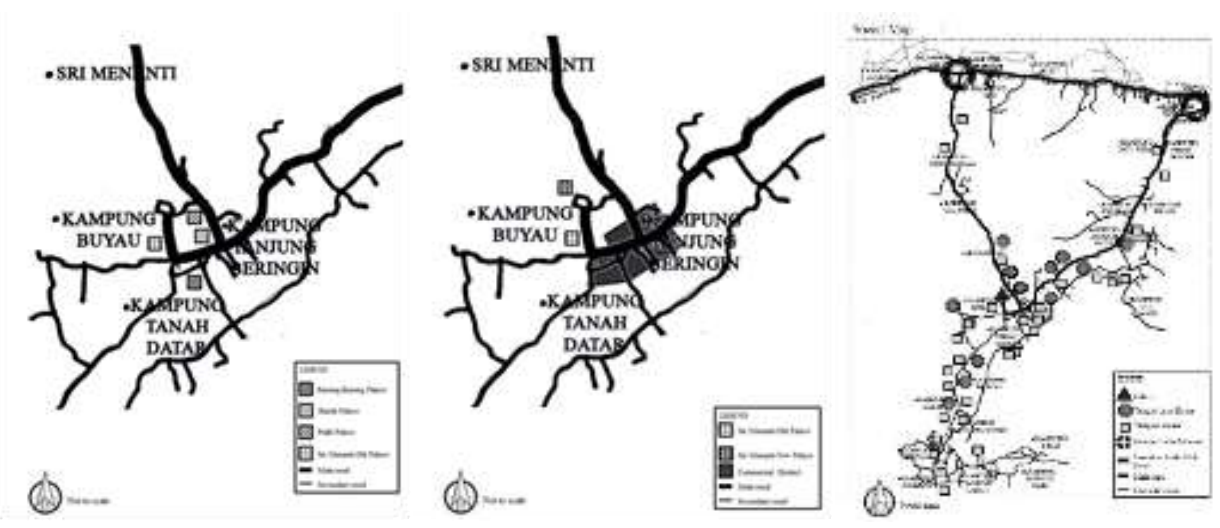

Figure 8: Map of the location of the four old palaces as written in history (left); map of current palace of Sri Menanti (centre); map showing the traditional houses of the Minangkabau people (right). Reproduced from Raja Shahminan et al., (2009) 
PLANNING MALAYSIA

Journal of the Malaysia Institute of Planners (2015)

The other type of building that exemplifies the great value of the traditional buildings in the Minangkabau architectural style are the old mosques located mostly in villages in Sri Menanti. As mentioned by Alias (2015), one of the 'Ketua Luak' in Sri Menanti, most of the people in the town follow Islam as their main religion. Therefore, the old mosques are considered to be among the dominant traditional buildings that might influence the development of the town of Sri Menanti.

Finally, another type of building that influenced the characteristics of the town was the traditional Minangkabau houses. Observation revealed that the traditional houses were built in different styles according to the Luak, reflecting the villages located in Sumatera. According to Abd. Kadir (2015), there are more than a hundred traditional houses that are over one hundred years old. Some of the houses are protected and preserved by the Museum but most are not, due to the problem of private ownership, which prevents the government or any other agencies from taking further action to preserve and protect these houses.

Hence, the results of this study reveal that the architectural features play an important role in shaping the built elements of the urban areas in the Royal Town of Sri Menanti. The preservation and conservation of the architectural elements is essential when developing and maintaining the unique image of the townscape elements in the royal town.

\section{Social Background of Sri Menanti}

Through the interviews, it was identified that in order to understand the social background of the local people in Sri Menanti, we first need to understand the town's political system. The hierarchy of the political strata in Sri Menanti Royal Town started with 'Yang Dipertuan Besar' at the highest level, followed by 'Undang', 'Lembaga', 'Buapak' and 'Perut'. During the interviews, Azhar (2015), the Head of Jawatan Kuasa Ketua Kampung (JKKK), stated that the setting of the urban fabric was influenced by the hierarchy of the political system. The design of the traditional buildings for the rulers was different from other villagers' houses in terms of height, roof shape and pattern. It is thus clear that the architectural style of a building reflects its social character.

\section{Cultural Significance of human activities in Sri Menanti}

Human activity is one component of the identity of places in Sri Menanti Royal Town that helped in creating a thematic point of concentration (Shamsuddin, 2011a). Through observation, it was found that fewer outdoor activities are conducted within the town area. However, most of the outdoor activities conducted in Sri Menanti take place in the centre of the town, specifically at the field located opposite the primary school and next to the library (see Figure 2). As it has an open field, this space has the ability to support gatherings in Sri Menanti. Most of these gatherings are conducted during the late evening, from 
Nor Zalina Harun, Dg. Norhidayah Fairuz \& Nor Adilla Nordin

The Roles of Urban Heritage in Determining the Image of the Royal Town of Sri Menanti, Negeri Sembilan

$5 \mathrm{pm}$ until 7pm. People also come to the lake next to the open field, which is called 'Lembah Londah Naga', to enjoy the scenery and take part in recreational waterbased activities such as fishing (see Figure 9).

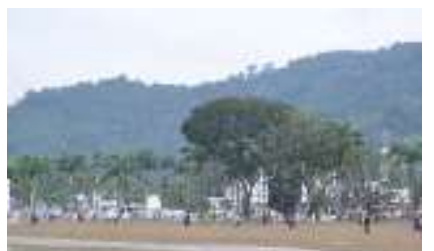

Figure 9: Some of the activities conducted at the open field and surrounding the lakes of Lembah Londah Naga.

However, as mentioned above, in relation to the social background of Sri Menanti, the local people strongly uphold the culture of 'Adat Perpatih'. This culture still strongly influence their daily activities (Saludin, 2007b). Referring to Figure 9, the open spaces are usually used by teenagers and young men. According to Azhar (2015), this is because of the cultural belief that the women should not waste their time socializing, but should instead focus on managing the household matters.

The 'warung kopi' (coffee shops) that exist adjacent to the road also create mini nodes to the town (see Figure 10). 'Warung kopi' activities are conducted during the early morning and late evening, until late night. These activities have an impact on the character of the townscape during this time, occurring at mini nodes in the town centre, and these sites also serve as an important space for supporting social gatherings among the local people.
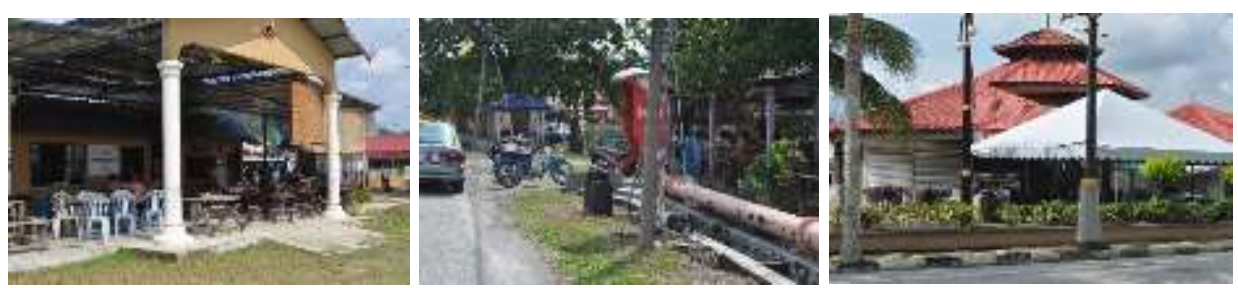

Figure 10: The 'warung kopi' located adjacent to the road that form the mini nodes in Sri Menanti.

Other types of node that have been identified based on the observation made include the mosques, which are major nodes during the Muslim prayer times: fajr, dhuhr, asr, maghrib and isha'. The mosques located within in the town are part of the street frontage and are places for peace and retreat for Muslims, supporting group gatherings. Historically, as mentioned by Abd. Kadir (2015), the mosques were used as meeting areas, and this was evident during the 
PLANNING MALAYSIA

Journal of the Malaysia Institute of Planners (2015)

British colonisation of Sri Menanti, as the colonial powers burned a number of mosques in Sri Menanti to prevent meetings among the local people. Therefore, the results show that mosques were one of the important nodes that help in characterising the town of Sri Menanti.

\section{DESIGN RECOMMENDATIONS}

As part of the research efforts to facilitate the conservation of built and cultural heritage of the Royal Town of Sri Menanti, a set of design guideline recommendations has been put in place to inform and guide related parties and conservation advocates on future conservation efforts.

Table 1: Design Recommendations

\begin{tabular}{|c|c|}
\hline $\begin{array}{c}\text { SIGNIFICANCE } \\
\text { ELEMENTS }\end{array}$ & DESIGN RECOMMENDATION \\
\hline Architectural features & $\begin{array}{l}\text { - Building with historic and architectural significance should be } \\
\text { restored in which original structure and layout are to be } \\
\text { retained. } \\
\text { - All features and detailing should be replaced with the most } \\
\text { similar design and pattern. } \\
\text { - Any alteration of structural elements should be done in the } \\
\text { most unobstructive way, if possible using original methods } \\
\text { and materials. }\end{array}$ \\
\hline Historical sites & $\begin{array}{l}\text { - Clear demarcation of land use and zoning of activities in the } \\
\text { historic area because some land uses and activities are } \\
\text { sensitive and cannot be mixed with certain activities. There } \\
\text { are also certain uses which are sensitive to new development } \\
\text { due to its special character and aesthetical values. } \\
\text { - In terms of the development control process, new guidelines } \\
\text { may need to be formulated as different land uses or zones may } \\
\text { require different guidelines based on their needs. } \\
\text { New development may be needed in some areas to generate } \\
\text { new activities and for overall enhancement. However such } \\
\text { redevelopment should be considered carefully in respect of } \\
\text { the existing scale, bulk grain and architectural style of the } \\
\text { physical fabric. } \\
\text { Entrance to these historic buildings and site can be charged at } \\
\text { minimal fees. These fees can be used to cover part of the } \\
\text { maintenance cost and improvement works of these buildings } \\
\text { and sites. }\end{array}$ \\
\hline Cultural activities & $\begin{array}{l}\text { - To promote new commercial and other suitable uses that can } \\
\text { complement the character of historic buildings, historic sites } \\
\text { and cultural activities. These activities will help to generate } \\
\text { income to the occupiers of these old buildings but also to } \\
\text { enhance the special attributes and environment of the area as } \\
\text { a whole. This will not only revitalize the socioeconomic of the } \\
\text { area, but also can improve the physical and visual } \\
\text { characteristics of the buildings within the area. }\end{array}$ \\
\hline
\end{tabular}


Nor Zalina Harun, Dg. Norhidayah Fairuz \& Nor Adilla Nordin

The Roles of Urban Heritage in Determining the Image of the Royal Town of Sri Menanti, Negeri Sembilan

- The cultural activities should be promoted as tourism products by the State Government. Part of the building, historical sites and cultural performances can be promoted within a tour package, historical trail or tours.

\section{CONCLUSION}

The urban heritage in Malaysia, often occupying an important and sometimes central location in present day towns, are localities of great cultural, architectural and historic significance. They derive their character, not only from the buildings and spaces of which they are comprised but also from the activities that occur there. The urban heritage has played a significant role in the history of Malaysia and its development. The site of the Seri Menanti Royal Town represents some of the special attributes which are rich in cultural and significance as it has been developed into the first administrative and early settlement in Negeri Sembilan. The special attributes which are important include the traditional features of the old buildings, special structures, traditional street patterns and its environment, traditional housing design and patterns and its daily activities. The diversity in character of the town together with its structural design, green space and cultural variety make the area unique and worthy of preservation. The research also concludes that conservation of physical and cultural heritage is an integral part of the urban conservation strategies of a royal town in Malaysia. The preservation and better maintenance of these heritage sites will add variety to the urban image while acting as a reminder and representation of the real identity of local culture and Malaysia. 
PLANNING MALAYSIA

Journal of the Malaysia Institute of Planners (2015)

\section{ACKNOWLEDGEMENTS}

The authors would also like to thank all parties who directly and indirectly contributed to the research, especially in the collection of data. Special thanks are dedicated to Encik Azhar, Head of Jawatankuasa Ketua Kampung (JKKK), Dato' Bangsa Balang Mohamad Dahalan Alias, the Head of the Luak in Sri Menanti Royal Town, Encik Nordin Bin Jonid, the Officer of Muzium Istana Sri Menanti, Encik Afian bin Abd. Kadir, the Officer of Muzium Kebudayaan and some of the old local people in Sri Menanti for their kindness and cooperation during the interview sessions.

\section{REFERENCES}

Abd. Kadir, A. (2015). The history and background of Sri Menanti Negeri Sembilan [Interview] (28 February 2015).

Abdul Hadi Hj. I. (1997). Beraja ke Johor, Bertuan Ke Minangkabau, Bertali ke Siak: Satu Rentetan Sejarah Negeri Sembilan. Warisan, 20(3), 53-67.

Alias, M. D. (2015). The socio-cultural background in Sri Menanti Negeri Sembilan [Interview] (8 March 2015).

Azhar (2015). The structure of town development [Interview] (7 March 2015).

Ban, S., 2012. Utusan Online: What are the criteria for a Royal Town? [Online] Retrieved from http://ww2.utusan.com.my/utusan/special.asp?pr= theMessenger $\& y=2012 \& d t=0209 \& p u b=$ theMessenger $\& s e c=$ Features $\&$ pg=fe_01.htm [Accessed 22 February 2015].

Dalmas L., Geronimi V., Mengin C., Noel J. \& Patin V. (2012). Methods for the Economic Valuation of Urban Heritage: A Sustainability-based. France: AFD.

Gullick, J. M. (2003). A History of Negri Sembilan. 1 Ed. Selangor: Perpustakaan Negara Malaysia.

Haji Ali, M. (1990). Senjata pendek melayu Yang Terdapat di Negeri Sembilan. In: N. Selat, Ed. Negeri Sembilan dahulu dan sekarang. Kuala Lumpur: United Selangor Press Sdn Bhd, pp. 229-241.

Ibrahim, N. H. (1995). Negeri yang Sembilan. Malaysia: Fajar Bakti Sdn. Bhd.

Jonid, N. (2015). The history of the Old Palace of Sri Menanti [Interview] (11 March 2015).

Lynch, K. (1990). The image of the city. 20th Ed. United States of America: The M.I.T Press.

Map of Sri Menanti Negeri Sembilan. [Online] Retrieved from https://www.google.com.my/maps [Accessed 1st March 2015]

MD Jani, H. H. \& Mohd Hussain, M. (2014). Reclaiming the Loss of the Minangkabau Cultural Landscape in Negeri Sembilan. Procedia - Social and Behavioral Sciences, 2014(153), 317-329. 
Nor Zalina Harun, Dg. Norhidayah Fairuz \& Nor Adilla Nordin

The Roles of Urban Heritage in Determining the Image of the Royal Town of Sri Menanti, Negeri Sembilan

Mohd Sam, S. \& Seow, T. (2013). Practice cultural of Orang Asli joking at Kampung Peta, Batu Pahat, Johor. University Tun Hussein Onn Malaysia (UTHM).

Muslim, N., Wan Hassan, W. Z. \& Umar, A. (2013). The Role of the Malay Royal Institutions According to the Constitution on Safeguarding Malay Position from the Higher Education Perspective. Educational Journal of Humanities and Social Science, 3(13), 267-272.

O'Keefe, T., Elliott, S. \& Naiman, R. J. (2015). Introduction to Watershed Ecology. United States: U.S Environmental Protection Agency.

Raja Shahminan R. N, Ibrahim F. K, Syed Ariffin S. A. I. \& Mursib G. (2009). Senibina Istana Lama. 1st Ed. Negeri Sembilan: Lembaga Muzium Negeri Sembilan.

Royal City Comprehensive Plan (2009). Draft city of Royal City Comprehensive Plan-2009 update. Ellenburg, Washington: Plan IT Consulting.

Saludin, M. R. (2007a). Naning Luak Terbilang. 1 Ed. Malaysia: Goalintelligent Publishing Sdn. Bhd.

Saludin, M. R. (2007b). Seri Menanti: Tanah Beradat Bermula di Sini. Negeri Sembilan: s.n.

Shamsuddin, S. (2011). Townscape Revisited: Unraveling the Character of the Historic Townscape in Malaysia. Penerbit UTM Press.

Tey, S. (2007). Recommendations of UNESCO General Conference. Phnom Penh, Municipality of Phnom Penh.

Walker, T. D. (1991). Planting Design (second edition), New York, John Wiley $\&$ Sons, Inc 